\title{
DETECTION AND IDENTIFICATION OF YELLOW MOSAIC STUNT DISEASE ON Petunia sp. USING NESTED PCR METHOD
}

\author{
Suryani Titi Astuti ${ }^{1}$, Sri Sulandari², Sedyo Hartono ${ }^{2}$, \& Susamto Somowiyarjo ${ }^{2}$ \\ ${ }^{1}$ Master Degree of Phytopathology, Faculty of Agriculture, Gadjah Mada University, Indonesia \\ Jl. Flora 1 Bulaksumur Yogyakarta 55281 \\ ${ }^{2}$ Department of Plant Protection, Faculty of Agriculture, Gadjah Mada University, Indonesia \\ Jl. Flora 1 Bulaksumur Yogyakarta 55281 \\ E-mail: sulandari77@ugm.ac.id
}

Manuscript received: 10 November 2020. Revision accepted: 18 January 2021.

\begin{abstract}
Detection and identification of yellow mosaic stunt disease on Petunia sp. using nested PCR method. Yellow mosaic stunt disease was found at some nurseries of Petunia in Sleman, Yogyakarta, also in Muntilan and Magelang Central Java. The disease was very important due to its ability reducing the quality and quantity of Petunia seedlings. The causal agent of the disease may be carried over to imported seeds and necessary to identify as a basic information for developing control strategies. This research was done by mechanical transmission on indicator plants. The observation of the causal agents was conducted using electron microscope with quick dipping method and the molecular detection was done using nested PCR with TobRT up1-TobRT do2 as the external primers and TobN up3-TobN do4 as the internal primers. Mechanical inoculation showed chlorosis symptoms that developed into local spot on Chenopodium amaranticolor as well as mosaic and vein banding on Nicotiana benthamiana. The observation using electron microscope showed rod-shaped virus particles sized approximately $300 \mathrm{~nm}$ and by PCR method produced around $568 \mathrm{bp}$ and $400 \mathrm{bp}$ DNA band. Based on the sequence analysis, the disease was caused by Rehmania mosaic virus. This type of Tobamovirus has 96\% similarity with ReMV-Japan. ReMV, a plant pathogen which was a member of Tobamovirus that has never been reported in Indonesia. This research was the first report of ReMV in Indonesia infecting Petunia as ornamental plant.
\end{abstract}

Key words: mosaic, nested PCR, petunia, Rehmannia mosaic virus, Tobamovirus

\section{INTRODUCTION}

Petunia is an ornamental plants that widely cultivated in many countries because they have beautiful and colorful flowers. This plant is usually propagated using stem cutting, and the plant has various types of flower and colours (Weidner, 1994). The plant is commonly used as an interior ornamental plant and as an exterior decoration in balcony or terrace. This plant is widely cultivated in several countries in Europe, America, and Asia. Recently, in Indonesia, there were many multinational seed companies propagated petunia seedlings in greenhouse for export commodity. The plant usually propagated from imported seed as parental plant for petunia hybrids. There are many types of petunia hybrids that produced of cross breeding. Currently the export of petunia seedlings with various type from Indonesia is increasing. To meet the increasing consumer demand, various types of seeds are imported from abroad as a source of parental seed. The imported seeds may has high risk since they could be contaminated by various pathogens from the origin countries, especially if the seeds was imported without proper and standardized measures of phytosanitary (Cohen et al., 1999).

There were several viruses infecting petunia such as: Potato virus Y (PVY), Tobacco mosaic virus (TMV), Tomato mosaic virus (ToMV), Alfalfa mosaic virus (AMV), Cucumber mosaic virus (CMV), and Petunia vein clearing virus (PVCV) (Lasemann, 1996). In Israel, petunia hybrids was commonly infected with PVCV that caused stunting with yellow leaves and vein banding of the younger leaves. PVCV is one species of viruses from Caulimoviridae family (RichertPoggeler \& Sheperd, 1997; Hull, 1984). The virus only transmitted by vegetative propagation but could not be transmitted by mechanical transmission or vector (Gera et al., 2000). PVCV infection on petunia hybrids had been reported in Germany and in United States (Lasemann \& Casper, 1973; Lockhart \& Lasemann, 
1997). Beside PVCV, TMV was reported in United States, Thailand, Israel, and England (Cohen et al., 1999; Khampirapeang et al., 2017; Saalau, 2017; Spence et al., 1996; Spence et al., 2001). Infected plants showed chlorotic spots that developed into yellow mosaic and finally the plant became stunted. Recently, TMV is a major problem in some countries, and the virus is easily transmitted to another plants in the greenhouse.

Yellow mosaic stunt disease symptoms on petunia hybrids that propagated from imported seed was observed in green house nurseries at Pakem Subdistrict, Sleman District (Yogyakarta Province) and Ngablak Subdistrict, Magelang District (Central Java Province). The disease was affect the quality and quantity of flower production massively. Therefore, it is necessary to detect and identify the causal agent of the disease, i.e. the use of dsRNA extraction, RTPCR, or Nested PCR (Pantaleo et al., 2001; Endarsih et al., 2017). Some part of this paper was presented at ISSAAS $20^{\text {th }}$ International Congress and General Meeting at Tokyo University of Agriculture, Tokyo, Japan on November 8-10, 2015.

\section{MATERIALS AND METHODS}

Research Site. The field survey was conducted at Petunia greenhouse cultivation at Pakem Subdistrict, Sleman District (Yogyakarta Province) and Muntilan Subdistrict, Magelang District (Central Java Province) in 2012-2014 and at Ngablak Subdistrict, Magelang District (Central Java Province) in 2015-2017. The sampling location was chosen because of a new case of mosaic disease in petunia. Symptoms observation was done visually by describing the symptoms and incidence of the disease in green house. Laboratory identification of the causal agents was conducted using isolate from Ngablak Subdistrict, Magelang District.

Sap Transmission. Sap transmission was conducted by crushing $0.1 \mathrm{~g}$ of diseased leaf with $1 \mathrm{~mL}$ buffer phosphate $0.005 \mathrm{M} \mathrm{pH} 7$ and $10 \mu \mathrm{L}$ mercaptoethanol. Sap was inoculated into the Chenopodium amaranticolor and Nicotiana benthamiana by mechanical inoculation (Almeida et al., 2018). The virus morphology was visualized using transmission electron microscope (JEOL JEM 1400, Japan) by a quick dipping method with negative stain using ammonium molybdat $1 \%$ pH 7 (Gebre-Selassie \& Marchoux, 1991; Latifah et al., 2008).

RNA Extraction. RNA extraction was done by following the method instructed by Qiagen. RNA as the result of extraction was then made into c-DNA using Reverse Transcriptation extraction kit from Takara (Toyobo, Japan), $8.5 \mu 1$ DEPC, primer TobRT do2 (Table 1) 5 pmol $1 \mu \mathrm{L}$, buffer $4 \mu \mathrm{L}$, RNA inhibitor $0.5 \mu \mathrm{L}$, dNTP $1 \mu \mathrm{L}$, RTase $1 \mu \mathrm{L}, 4 \mu \mathrm{L}$ product RNA extraction were added into the microtube and then put into incubation at $65^{\circ} \mathrm{C}$ for $5 \mathrm{~min}$, at $42^{\circ} \mathrm{C}$ for $60 \mathrm{~min}$, at $95^{\circ} \mathrm{C}$ for $5 \mathrm{~min}$ and at $4{ }^{\circ} \mathrm{C}$. The cDNA result subsequently used as template for nested PCR as following step.

DNA Amplification. DNA amplification was carried out using SuperHot MasterMix (Bioron) according to the kit manual. The first incubation was done at a temperature of $95^{\circ} \mathrm{C}$ for $5 \mathrm{~min}, 94^{\circ} \mathrm{C}$ for $1 \mathrm{~min}, 46^{\circ} \mathrm{C}$ for $1 \mathrm{~min}, 72{ }^{\circ} \mathrm{C}$ for $1 \mathrm{~min}, 72^{\circ} \mathrm{C}$ for $5 \mathrm{~min}$; the second incubation was done at $95^{\circ} \mathrm{C}$ for $5 \mathrm{~min}, 94^{\circ} \mathrm{C}$ for $1 \mathrm{~min}$, $61^{\circ} \mathrm{C}$ for $1 \mathrm{~min}, 72^{\circ} \mathrm{C}$ for $1 \mathrm{~min}, 72^{\circ} \mathrm{C}$ for $5 \mathrm{~min}$. Nested PCR used two pairs of TobRT up1-TobRT do 2 primer as the external primer and TobN up3-TobN do4 as the internal primer (Dovas et al., 2004) (Table 1).

Sequencing and Analysis. The sequencing process conducted using direct sequencing method provided by PT. Genetika Science Indonesia. Sequence result analyzed using bioinformatics software ChromasPro 1.49 , Genetyx 7.0 which was then compared to the DNA Data Bank of Japan (DDBJ) collection of Tobamovirus sequence result. The phylogenetic analysis used Treeview 1.6.6 program.

\section{RESULTS AND DISCUSSION}

Disease Symptom and Incidence. Between 2012 to 2014 at Pakem Subdistrict and Muntilan Subdistrict, the

Table 1. Primers used in this study

\begin{tabular}{clc}
\hline Name & \multicolumn{1}{c}{ Sequence (5'-3') } & Target size \\
\hline TobRT up1 & GARTAYSCIGCIYTICARAC & \multirow{2}{*}{ 568bp } \\
TobRT do2 & BGCYTCRAARTTCCA & \multirow{2}{*}{ 400bp } \\
\hline TobN up3 & GGCGYTGCARACIATHGTITAYCA & \\
TobN do4 & GTRTTICCIATRAAIGTIGTIACRTC & \\
\hline
\end{tabular}


percentage of disease incidence could reach up to $20.0 \%$ annually. In 2015 to 2017 the disease also reported found at Ngablak Subdistrict with disease incidence was about $7.0-15.0 \%$. Based on the observation, the diseased petunia showed two type of symptoms: yellow mosaic and stunting (Figure 1B); leaves malformation and mosaic yellow symptom (Figure 1C).

Commonly, the yellow mosaic and stunting symptom were found on plants grown from imported seeds, while yellow mosaic symptom were mostly found on plants that propagated by stem cutting. Growing on test assay of imported seed that used as a parental hybrids showed yellow mosaic symptom that became stunting with incidence was about $1.0 \%$, while on stem cutting propagated seedling the mosaic symptoms was about $30.0 \%$. This result indicated that the pathogen was seed borne and originated from the country of imported seed. Moreover, the virus also could be transmitted easily using cutting tool during plant propagation. Although the numbers of infected seed was very low, but it is very important case because the infected seed could be an inoculum source of the disease in the field. In this research revealed that seedling in nurseries that propagated by stem cutting from the parental plants showed the number of the disease symptom was higher than the parental plant was used. The infected seedling at the green house would be as an inoculum source of the disease, and the virus would spread over easily by mechanical transmission, through vegetative propagation plant using stem cutting. This condition is potentially as a trigger of the epidemic of the disease. Based on the visual symptoms showing mosaic and stunting, the pattern of spread of mechanically easily transmitted pathogens was suspected to have similar causes with TMV infection. By visual symptoms, it was similar with the disease on Petunia spp. that caused by TMV that has been reported. TMV as an causal agents of the disease was supported by the observation in a greenhouse that there were no Aphis spp. as a vector of Cucumber mosaic virus (CMV) and Potato virus $Y$
(PVY) that also could induce mosaic symptom on Petunia spp. Based on the data proved that the mosaic and stunting symptom on petunia was caused by TMV eventhough the symptom was similar with PVY infection (Saalau, 2017; Spence et al., 1996; Spence et al., 2001). TMV was not transmitted by insect vectors but PVY could be transmitted by some insect vectors. There were not found weeds inside and surrounding the greenhouse area. Weeds were reported as an alternative host of some viruses and as a breeding site of some insect vector.

Pathogen Identification. Mechanical inoculation on C. amaranticolor showed chlorotic symptom that turned into necrotic spots in 5 days after inoculation (Figure 2A). Systemic symptom was found in $N$. benthamiana. The early symptom showed yellow spots on the vein at 8 days after inoculation and then spread throughout the leaves. Eighteen after inoculation, vein banding symptom appeared as the leaves turned yellow and vein clearing (Figure 2B). The viruses then spread systemically and 30 days after inoculation, the sprouting young leaves showed mosaic symptom as well (Figure 2C). Observation using electron microscope discovered a lot of rod-shaped virus particles of around $300 \mathrm{~nm}$ long (Figure 2D). Based on the mosaic symptom found in $N$. benthamiana, the shape and size of the virus particle was very similar with the symptom caused by TMV infection (Van Regenmortel et al., 2000). TMV infected petunia had also been reported to infect Nicotiana spp. According to the observation using electron microscope, the particles were found to be in the form of short and rods shape (Spence et al., 2001).

PCR analysis had a high sensitivity to detect PVCV in petunia and that make it the appropriate diagnostic method for virus detection using in vitro on Petunia parental plant (Zeidan et al., 2000). This study conducted using nested PCR (RT-n-PCR) detection with the first amplification resulted virus DNA band of around 568 bp (Figure 3A) while the second amplification
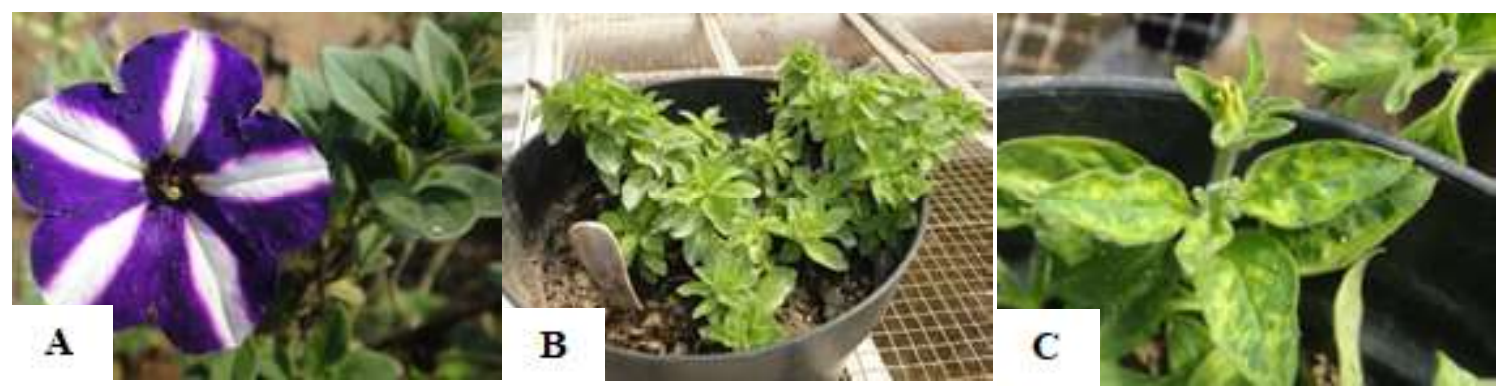

Figure 1. The disease symptom on petunia hybrida: (A) Healthy plant; (B) Yellow mosaic and stunting; (C) leaf malformation and mosaic yellow symptom. 
resulted in virus DNA band of around 400 bp (Figure $3 \mathrm{~B})$. It is supported that the causal agents of petunia disease was a virus of Tobamovirus species. Conventional PCR detection had been consecutively conducted to detect virus on various plants. But sometimes, some types of virus could not be detected using conventionally PCR method thus modification such as nested PCR was necessary. Nested PCR successfully detected a number of important viruses on olive plant cutting which was initially difficult to do using conventional PCR method (Pantaleo et al., 2001). Nested PCR was also used regularly by South Korea's quarantine agency to detect Tobacco ringspot virus (TRSV) on various plants that propagated by seed (Lee et al., 2015). Based on the visual symptom on the indicator plant, the particle morphology and PCR analysis proved that the mosaic and dwarf on petunia was infected by Tobamovirus.

Based on the Tobamovirus nucleotide sequence analysis, the causal agent of the petunia disease in this study was identified as Rehmannia mosaic virus (ReMV) (Figure 4). Homology of nucleotide sequence from Tobamovirus obtained from this research showed several similarity homology compared to another isolates of Tobamoviruses from several countries (Table 2).
ReMV is a species of relatively new Tobamovirus. The virus was reported for the first time in Henan, China during 2000-2003 infecting Rehmannia glutinosa (Scrophulariaceae) (Zhang et al., 2004; Zhang et al., 2008). In Taiwan, TMV infected Rehmannia glutinosa had also been reported by Liao et al. (2007) with the virus infected $R$. glutinosa and caused mosaic symptom while locally infected $C$. amaranticolor, C. quinoa dan N. tabacum cv. VAMHicks caused necrotic. Observation using electron microscope showed the existence of rod-shaped particle of $300-310 \mathrm{~nm}$ in size and $16-18 \mathrm{~nm}$ in diameter. Characteristics of this virus were identical to those of petunia ReMV isolate studied here.

ReMV is a member of Tobamoviruses and it has a wide range of host including tobacco and rehmania (Zhang et al., 2008). This virus could transmitted easily by mechanical inoculation and by seed contamination. Tobamovirus infection in plants could reduce plant growth at vegetative and generative phase (Akin \& Nurdin, 2003). In this research, we used petunia samples from Ngablak and Muntilan. The detection method using PCR showed those samples were positively infected by ReMV. Similar to other Tobamoviruses in plants, the ReMV-infected plants
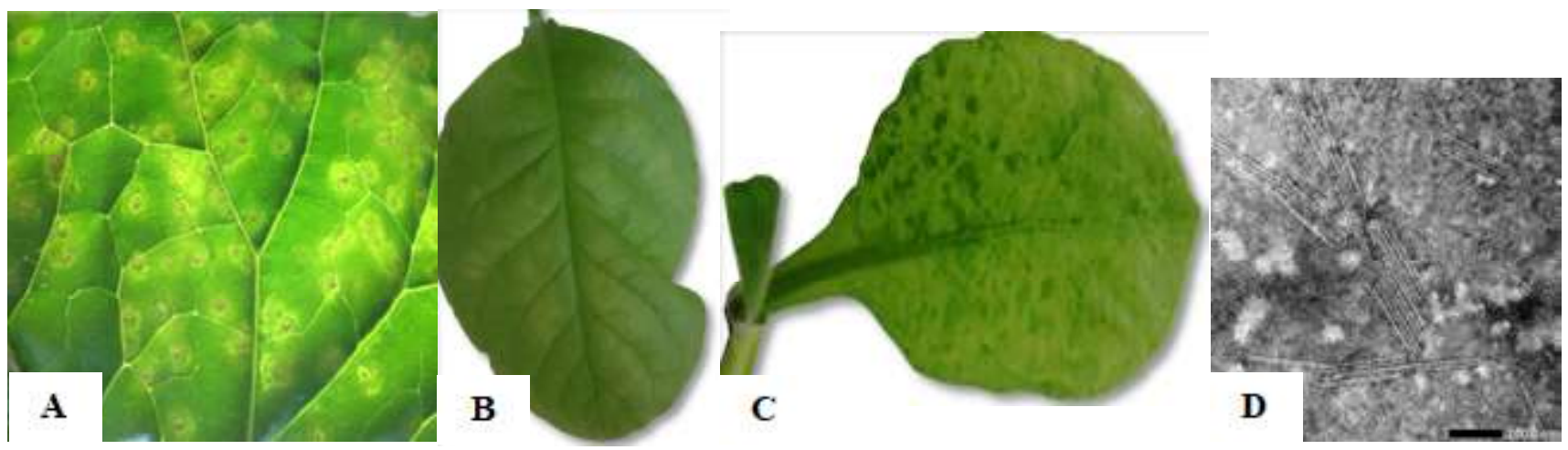

Figure 2. (A) Local necrotic on C. Amaranticolor; (B) Vein banding symptom on N. Benthamiana; (C) Mosaic symptom on $N$. benthamiana young leaves; (D) Micrograph electron of Tobamovirus particle from infected Petunia. The particle was originated from a specimen that was coloured negative using ammonium molybdat $1 \% \mathrm{pH}$ 7. The bar represents $200 \mathrm{~nm}$.
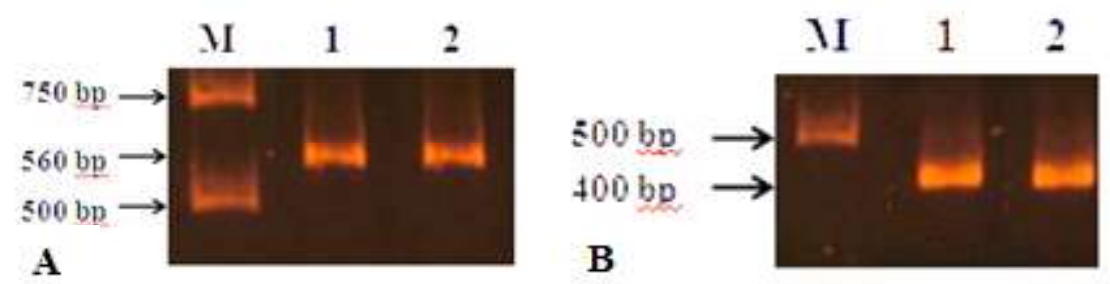

Figure 3. Detection of I obamovirus with polymerase chain reaction using: (A) TobRT up1-TobRT do2 primer; (B) TobN up3-TobN do4 primer, M: marker $1 \mathrm{~kb}$; 1: Petunia leaves with mosaic symptom; 2: necrotic symptom on C. amaranticolor. 
could became stunted and productivity loss. Infected petunia in this research showed several symptoms including stunting and mosaic. This problem became a major disease and caused significant economic loss for the farmers and nurseries. Tobamovirus control efforts had been quite difficult because virus had a wide host in the field and easily transmitted by mechanical inoculation as well through seed contamination.
There was no previous report of ReMV incidence in Indonesia. This research was the first report of ReMV in Indonesia infected petunia as ornamental plant. ReMV isolate was recently used as a model in various plant virus studies in our laboratory (Endarsih et al., 2017; Nurviani et al., 2018; Putri et al., 2018). The result of this research expected to be used for developing strategy to the tobamoviruses in ornamental plants.

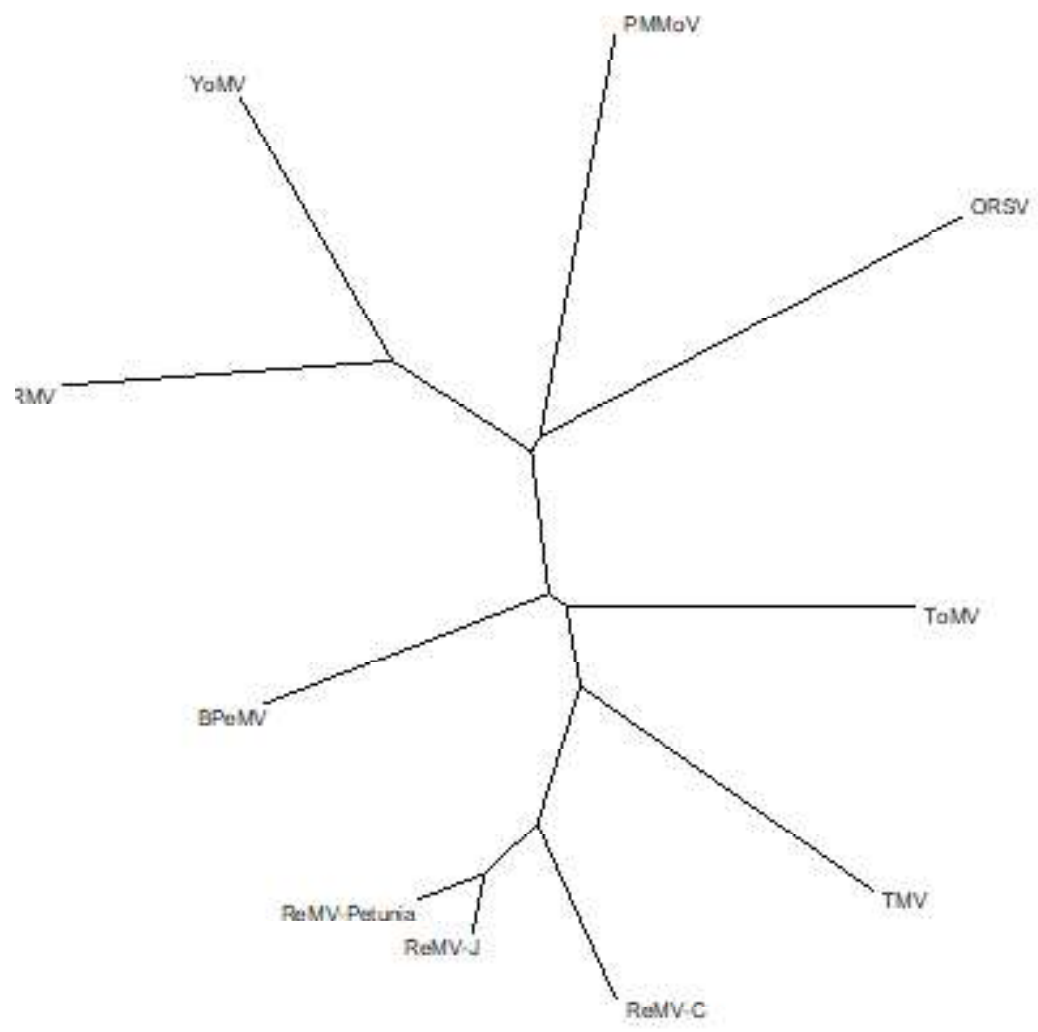

Figure 4. Phylogenetic tree derived from nucleotide structure for ORF2 ReMV-Petunia gen. ORF2 ReMV-Petunia gen analysis was carried out using Clustal W program from DDBJ and observed using Treeview 1.6.6.

Table 2. Comparison between ReMV-Petunia isolate and other Tobamovirus isolates

\begin{tabular}{lcl}
\hline Tobamovirus isolate & Nucleotide identity (\%) & Accession number \\
\hline ReMV-J & 96 & AB628188 \\
ReMV-C & 89.3 & EF375551 \\
RMV & 71.9 & GQ401365.1 \\
YoMV & 71.2 & D38444.1 \\
BPeMV & 80.6 & DQ355023.1 \\
ORSV & 70.2 & NC_001728 \\
PMMoV & 73.6 & EF061142.1 \\
TMV & 80.8 & D78608.1 \\
ToMV & 80.6 & AJ417701.1 \\
\hline
\end{tabular}




\section{CONCLUSION}

Yellow mosaic stunt disease on Petunia spp. was caused by Rehmannia mosaic virus (ReMV). The virus was a new species of Tobamovirus in Indonesia. Nucleotide sequence analysis showed that Indonesian ReMV isolate had 96\% the homology with ReMV isolates from Japan. This research was the first report of ReMV in Indonesia infected petunia as ornamental plant. The virus should be monitored intensively because of had the same characteristic with the mechanically transmitted TMV that was difficult to control. The virus might cause serious problem to various plants in Indonesia.

\section{ACKNOWLEDGMENTS}

Our gracefully thanks to PT. Takii Indonesia, which providing the petunia samples used in this study.

\section{REFERENCES}

Akin HM \& Nurdin M. 2003. Pengaruh infeksi TMV (Tobacco mosaic virus) terhadap pertumbuhan vegetatif dan generatif beberapa varietas cabai merah (Capsicum annuum L.). J. HPT Tropika. 3(1): 10-12.

Almeida JEM, Figueira AdR, Duarte PdSG, Lucas MA, \& Alencar NE. 2018. Procedure for detecting tobamovirus in tomato and pepper seeds decreases the cost analysis. Bragantia. 77(4): 590-598.

Cohen J, Sikron N, Shuval S, \& GeraA. 1999. Susceptibility of vegetatively propagated petunia to tobamovirus infection and its possible control. HortScience.34(2): 292-293.

Dovas CI, Efthimiou K, \& Katis NI. 2004. Generic detection and differentiation of tobamoviruses by a spot nested RT-PCR-RFLP using dI-containing primers along with homologous dG-containing primers. J. Virol. Methods. 117(2): 137-144.

Endarsih W, Hartono S, \& Sulandari S. 2017. Improvement of simple dsRNA virus extraction method for RT-PCR of three plant viruses. JPTI. 21(2): 106-113.

Gebre-Selassie K \& Marchoux G. 1991. Identification and characterization of tobamoviruses strains infecting L-resistant genotypes of peppers in France. J. Phytopathol. 131(4): 275-289.
Gera A, Sikron N, Cohen J, \& Zeidan M. 2000. First report of Petunia vein clearing virus in Isreal. Plant Dis. 84(2): 201.

Hull R. 1984. Caulimovirus group. CMI/AAB description of plant viruses, no. 295.

Khamphirapaeng P, Cheewangkoon R, McGovern RJ, Wong SM, \& To-Anun C. 2017. Detection of Tobacco mosaic virus in petunia and tobacco by light microscopy using a simplified inclusion body staining technique. IJAT. 13(2): 163-168.

Lasemann DE \& Casper R. 1973. Electron microscopy of petunia vein clearing virus, an isometric plant virus associated with spesific inclusions in petunia cells. Phytopathology. 63: 1118-1124.

Lasemann DE. 1996. Viruses recently detected in vegetatively propagated Petunia. Acta Hort. 432(10): 88-95.

Latifah, Hidayat SH, \& Sujiprihati S. 2008. Metode penapisan cabai (Capsicum annuum L.) untuk ketahanan terhadap Chilli veinal mottle virus (ChiVMV) dan Cucumber mosaic virus (CMV). J. HPT Tropika. 8(2): 146-153.

Lee S, Lee G, Choi IC, \& Rho JY. 2015. Development of PCR diagnostic system for detection of the seed-transmitted tobacco ringspot virus in quarantine. Indian J. Microbiol. 55(2): 231-233.

Liao JY, Hu CC, Kao JL, \& Deng TC. 2007. Identification of Tobacco mosaic virus infecting Rehmannia glutinosa. Plant Pathology Bulletin. 16(2): 61-69.

Lockhart BEL \& Lasemann DE. 1997. Occurrence of petunia vein-clearing virus in the U.S.A. Plant Dis. 82(2): 262.

Nurviani, Somowiyarjo S, Sulandari S, \& Subandiyah S. 2018. The inhibition of Tobamovirus by using the extract of banana flower. JPTI. 22(2): 181-185.

Pantaleo V, Saponari M, \& Gallitelli D. 2001. Development of a nested PCR protocol for detection of olive-infecting viruses in crude extracts. J. Plant Pathol. 83(2): 143-146.

Putri RA, Sulandari S, Sumardiyono C, \& Arwiyanto T. 2018. Resistance response of tobacco to Tobamovirus with biological agents as inducer. JPTI. 22(2): 201-209.

Richert-Pöggeler KR \& Sheperd RJ. 1997. Petunia veinclearing virus: a plant pararetrovirus with the cone 
sequences for an integrase function. Virology. 236(1): 137-146.

Saalau E. 2017. Horticulture and home pest news. Iowa Satte University of Science and Technology. Available from: https:// hortnews.extension.iastate.edu/. accessed on January $10^{\text {th }} 2020$.

Spence NJ, Barker I, O’Neill T, Bennison J, \& Wright D. 1996. Viruses in trailing petunias. HDC Fact Sheet No. 04/96: Horticultural Development Council, United Kingdom.

Spence NJ, Sealy I, Mills PR, \& Foster GD. 2001. Characterization of a tobamovirus from trailing petunias. Eur. J. Plant Pathol. 107(6): 633-638.

van Regenmortel MHV, Fauquet CM, Bishop DHL, Carstens EB, Estes MK, Lemon SM, Maniloff J, Mayo MA, McGeoch DJ, Pringle CR, \& Wickner
RB. 2000. Virus Taxonomy: Seventh Report of the International Committee on Taxonomy of Viruses. Academic Press, San Diego.

Weidner E. 1994. Supertunias more than just petunia. Ohio Florist's Ass. Bull. 777: 4-5.

Zeidan M, Sikron N, Cohen J, \& Gera A. 2000. Improved detection of petunia vein clearing caulimovirus. HortScience. 35(7): 1279-1282.

Zhang ZC, Zhang LF, Qiao Q, Wang YJ, \& Jin XL. 2004. Identification of viral pathogens of Rehmannia glutinosa disease in Henan Province. Acta Phytopathol. Sin. 34(5): 395-399.

Zhang ZC, Lei CY, Zhang LF, Yang XX, Chen R, \& Zhang DS. 2008. The complete nucleotide sequence of a novel Tobamovirus, Rehmannia mosaic virus. Arch. Virol. 153(3): 595-599. 